\title{
Secretin cells in coeliac disease
}

\author{
JULIA M. POLAK, A. G. E. PEARSE, SUSAN VAN NOORDEN, S. R. BLOOM, \\ AND MARY A. ROSSITER
}

From the Department of Histochemistry, Royal Postgraduate Medical School, London, the Department of Clinical Research, Middlesex Hospital, London, and the Department of Gastroenterology, Queen Elizabeth Hospital, London

SUMMARY Immunofluorescence (anti-secretin), cytochemical, and ultrastructural studies were carried out on jejunal biopsies from 16 children with coeliac disease and from 17 controls with suspected malabsorption but normal jejunal morphology.

In 11 of the 16 coeliacs there was generalized hyperplasia of endocrine cells and, specifically, of the secretin (S) cells.

Further studies, on adult coeliacs as well as on children, combined with serum secretin assays, may establish whether the $\mathrm{S}$ cells are abnormally storing hormone because of inability to release it or because of excess production.

Present observations suggest that abnormal secretion of certain gut hormones may be involved in the malfunction of the intestine in coeliac disease.

In this disorder the secretory response of the exocrine pancreas to a standard meal is reduced (Worning, Müllertz, Thaysen, and Bang, 1967), as it also is after perfusion of the intestine with amino acids (which stimulate cholecystokinin secretion). After intravenous pancreozymin it has been reported to be normal (Di Magno, Go, and Summerskill, 1969). Similarly, it has been shown by Wormsley (1970) that in coeliacs there is a reduced pancreatic bicarbonate response to intestinal acidification (which should stimulate release of secretin) but a normal bicarbonate response to the injection of secretin. Low-Beer, Heaton, Heaton, and Read (1971) showed that coeliacs respond with minimal contraction of the gallbladder after a fatty meal, but with normal contraction after injection of cholecystokinin (CCK), and Novis, Bank, and Marks (1972) found that exocrine pancreatic secretion was normal after injection of secretin and pancreozymin (PZ) except in cases of severe malnutrition. Braganza and Howat (1971), on the other hand, found that there was an impaired response to $\mathrm{CCK} / \mathrm{PZ}$ in more than $50 \%$ of coeliacs while after secretin stimulation the bicarbonate output was normal. They suggested that there was an intrinsic deficiency in the response of the gallbladder in coeliac disease. In a group of

Received for publication 26 July 1973. children with coeliac disease only minimal changes in serum insulin were observed during a glucose tolerance test (Grant, 1973).

The evidence summarized above points to the conclusion that the pancreas itself is capable of normal function in coeliac disease but that normal stimulation by secretin and/or $\mathrm{CCK} / \mathrm{PZ}$ is not present, perhaps because the release mechanism for these hormones is impaired.

These findings, together with our own (unpublished) observation of intestinal endocrine cell hyperplasia in a single case of adult coeliac disease, led us to undertake a study of the intestinal endocrine cells in a series of children with coeliac disease.

Individual hormone-secreting cells can now be visualized by means of immunofluorescence techniques, provided that specific antisera are available. In the normal intestine secretin cells are very difficult to locate by these methods, either because they are sparsely distributed or else because under normal conditions they secrete their product rather than store it. We postulated that failure of hormone release, if present, would cause the various endocrine cells to store their product and thus provide positive immunofluorescence.

The immediate purposes of the study were thus to determine whether there is a true hyperplasia of endocrine cells, as well as of enteroblasts (Booth, 1970), in coeliac disease, and whether the secretin cells are hyperactive and empty or abnormally full of hormone. 


\section{Material and Methods}

Intestinal mucosa was obtained with a Crosby capsule placed at or just beyond the ligament of Treitz in the following subjects:

\section{COELIAC DISEASE}

Sixteen children (aged 9 months to 14 years), with subtotal or partial villous atrophy, who subsequently responded clinically to a gluten-free diet or who had relapsed on a diet containing gluten.

\section{CONTROLS}

Seventeen children (aged 12 months to 14 years), with suspected malabsorption or small stature, who had normal jejunal morphology.

Orving to the small size of the mucosal samples the number of procedures which could be carried out on any one biopsy was limited.

\section{Immunofluorescence}

\section{FIXATION}

Part or all of the sample was immediately fixed in a solution of $10 \%$ carbodiimide hydrochloride (CDI) (Sigma) in $0.1 \mathrm{M}$ phosphate-buffered normal saline (PBS) at $\mathrm{pH} \mathrm{7.0.} \mathrm{This} \mathrm{has} \mathrm{been} \mathrm{found} \mathrm{to} \mathrm{be} \mathrm{a}$ satisfactory fixative for both secretin and enteroglucagon (Polak, Bloom, Coulling, and Pearse, 1971a). Samples were fixed at $4^{\circ} \mathrm{C}$ for three hours and then transferred to a solution of $7.5 \%$ sucrose in PBS at $4^{\circ} \mathrm{C}$ for storage.

\section{PREPARATION OF ANTISERA}

The antiserum was raised in New Zealand white rabbits to pure porcine secretin coupled to bovine serum albumin. The antigen was emulsified in complete Freund's adjuvant and injected in multiple subcutaneous sites at three-monthly intervals. Serum was harvested after two injections at this interval. The total dose of secretin per injection was $100 \mathrm{mg}$. The titre of the antisera, tested by ability to bind $50 \%$ of $50 \mathrm{pg}{ }^{125}$ I secretin, was $1 / 80000$. There was no detectable cross-reaction with vasoactive intestinal polypeptide (VIP), glucagon, or gastric inhibitory polypeptide (GIP).

\section{IMMUNOLOGICAL STAINING}

An indirect fluorescent antibody staining technique was carried out (Coons, Leduc, and Connolly, 1955).

\section{PROCEDURE}

After fixation in $10 \% \mathrm{CDI}$ in PBS and storage in PBS with $7.5 \%$ sucrose the tissue was rinsed in PBS to wash out the sucrose. It was then blotted dry, mounted on a cork disc with the aid of Ames OCT compound, and frozen rapidly in melting Arcton 22. Sections $5 \mu$ thick were cut in a cryostat and picked up on slides which had been previously coated with formol-gelatin ( $1 \%$ formaldehyde in $2 \%$ gelatin). Sections were allowed to dry at room temperature and a drop of the antiserum was then applied. Whole serum was used diluted appropriately ( 1 in 10 , as previously established for control tissue) with phosphate-buffered saline. The sections were left in a damp atmosphere (a covered Petri dish containing water-saturated cottonwool) for one hour at room temperature. A known positive control section was included with each test as was a negative control on the test section, using non-immune serum. After one hour the antiserum was washed off in three changes of PBS of five minutes each, with gentle agitation of the washing solution by means of a magnetic stirrer. The slide was then carefully dried except for the area of the section and replaced in the Petri dish. The second layer of antibody was goat antirabbit gamma-globulin conjugated with fluorescein isothiocyanate (Hyland). This serum was diluted 1 in 10 with phosphate-buffered saline. After an hour the excess serum was washed off as before and the sections were mounted in buffered glycerine (1 part of PBS to 9 parts of glycerine) and examined in a fluorescence microscope.

\section{Histology}

FIXATION

Occasional samples of mucosa were fixed in methanol-free formaldehyde (MFF) (Polak, Bussolati, and Pearse, 1971b), and processed and embedded in wax for histological staining. Other histological fixatives, such as Bouin's fluia or $6 \%$ glutaraldehyde, were also occasionally used.

\section{HISTOLOGICAL STAINING}

The stains used were those which have been found to be helpful in identifying endocrine cells of the APUD series (Pearse, 1968, 1969). These were the Grimelius (1968) method for argyrophilia and an adaptation of McConnail's lead haematoxylin method (Solcia, Capella, and Vassallo, 1969). When CDI-fixed or MFF-fixed sections were used they were postfixed in Bouin's fixative before carrying out the argyrophil reaction or in $6 \%$ glutaraldehyde before the lead haematoxylin stain. When these had been the primary fixatives no further processing was necessary. Sections from 11 coeliacs and 14 control cases were stained by these methods.

\section{Electron Microscopy}

Where sufficient material was available part of the 
sample was chopped into $1 \mathrm{~mm}$ cubes and fixed in $3 \%$ glutaraldehyde in phosphate buffer $(0 \cdot 1 \mathrm{M}$, $\mathrm{pH} 7 \cdot 0$ ), followed by postfixation in osmium tetroxide, dehydration through graded alcohols and propylene oxide, and Araldite embedding for electron microscopy. Ultrathin sections of the Araldite-embedded material were stained with lead citrate and uranyl acetate, and were examined in an AEI 6B electron microscope.

\section{Results}

\section{IMMUNOFLUORESCENCE}

\section{Secretin}

In nine out of the 16 coeliac biopsies studied secretin (S) cells could clearly be distinguished by their bright fluorescence compared with the background (fig 1). Control staining with non-immune serum was negative. Frequently two or more secretin cells appeared in the same low-power microscopic field. In two cases rather fewer, and less bright, secretin cells were seen. In the remaining five cases no secretin cells could be identified.

One of the controls gave a result comparable to the positive test samples; in four only one or two $S$ cells were found. In the remaining 14 no $S$ cells were detected.

\section{HISTOLOGY}

Most of the coeliac biopsies had subtotal villous atrophy. Three showed partial villous atrophy. All the controls had normal mucosal architecture.

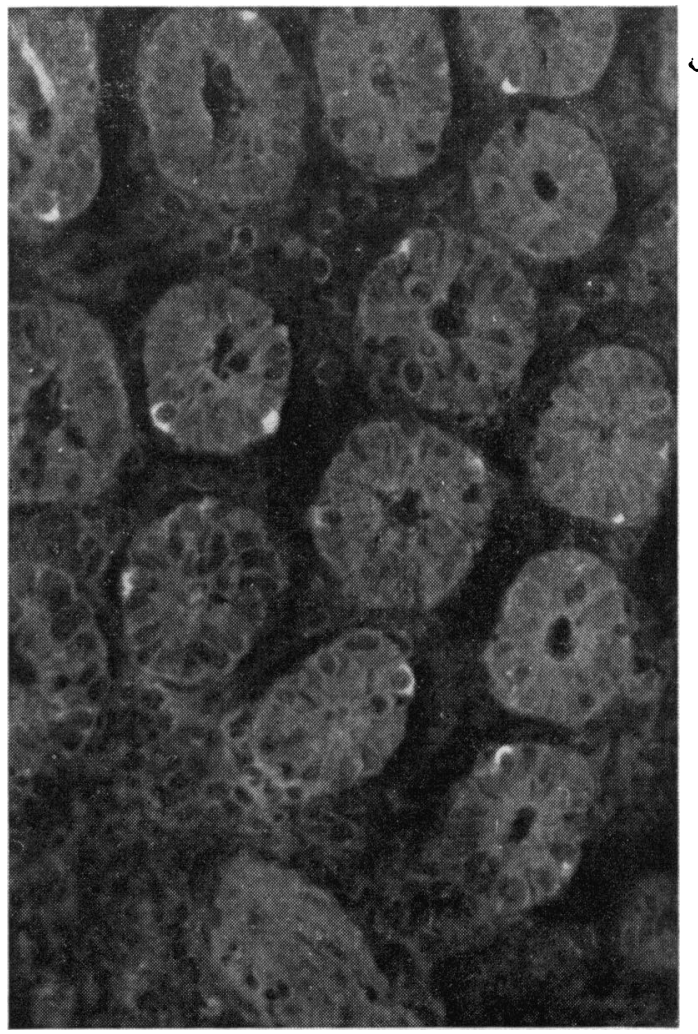

Fig 1 Jejunal biopsy. CDI Fixation, cryostat section. Indirect immunofluorescence preparation shows secretin $(S)$ cells widely distributed in the glands, nearly every gland having at least one example. $\times 120$

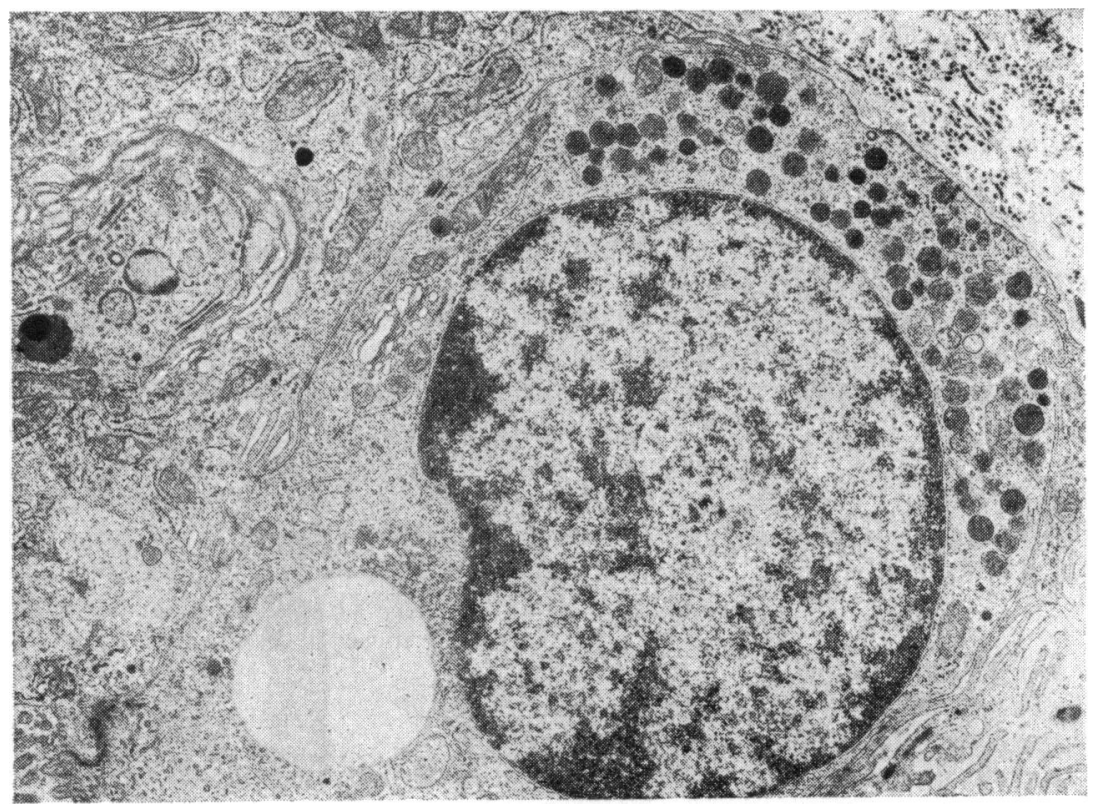

Fig 2 Jejunal biopsy. Glutaraldehyde-osmium fixation. Electron micrograph. Shows a typical secretin (S) cell, containing basally located granules with characteristic halo and dense core. Its apical process (upper left) terminates in stumpy microvilli in the lumen of the gland. This cell shows no signs of high secretory activity. $\times 11250$ 
Staining for endocrine cells

Cell counts were carried out on all biopsies in the control and coeliac series. Each biopsy was then graded $3+, 2+$, or $1+$. Large $(3+)$ numbers of argyrophilic cells were found in four of the coeliacs, moderately large $(2+)$ numbers in six, and a smaller number $(1+)$ in a single case. In the control series argyrophil cells were very numerous in one case, moderately so in seven, and much less so in six cases.

With lead haematoxylin, and the same grading procedure, 10 of the 11 coeliac cases showed numerous or very numerous positively stained cells. In a single case no stained cells could be found. Two of the control series had numerous stained cells, seven moderately numerous, and four had small numbers only. When, on occasion, the sections became detached during staining no count was recorded.

\section{ELECTRON MICROSCOPY}

The large number of $S$ cells observed by light microscopic techniques and immunofluorescence in the positive sample from coeliac cases was reflected in the large number of typical $\mathbf{S}$ cells which were seen under the electron microscope (fig 2). In addition, intermediate (I), enterochromaffin (EC), and entercglucagon (EG) cells were usually present, in moderate numbers, in both control and coeliac biopsies.

\section{Discussion}

In $60 \%$ of the cases of coeliac disease secretin (S) cells were visible in greater than normal numbers, both compared with the current series of controls and with our past experience of duodenal and jejunal biopsies.

The $\mathbf{S}$ cells appeared by the immunofluorescent technique to be full of hormone, a fact essentially confirmed by their fully granulated state observed by electron microscopy. It is not possible to say from the morpholog:cal evidence whether they are full because of a failure of release, or whether they are hyperactive owing to a failure of the feedback mechanism and are therefore producing an excessive amount of hormone. It is known that $\mathbf{S}$ cells are stimulated by high acid levels in the intestine and possibly they may not release their product under low acid conditions. A parallel situation is known in the case of the gastrin-producing $G$ cells of the pyloric antrum which, in the presence of high acid levels, are shown by immunofluorescence to be full of hormone. When low acid levels are present the $G$ cells release their hormone and are poorly visible or invisible by immunofluorescent reactions for gastrin (Polak, Stagg, and Pearse, 1972). Low acid levels are known to be present in coeliac disease (Andersen, 1947). Considering this, and the pathophysiological evidence quoted in the introduction, the results of our immunofluorescence tests make it reasonable to suppose that the $S$ cells in coeliac disease are prevented from releasing their hormone by some factor yet to be determined. Some of the argyrophil and lead-haematoxylin-stained cells, which are present in all the biopsies but in excess in some of the coeliacs, are presumably $S$ cells. The staining characteristics of this cell type have already been established (Capella, Solcia, and Vassallo, 1972; Polak, Coulling, Bloom, and Pearse, 1971c). The identity of the other endocrine cells in the samples has not yet been determined. There is apparently some degree of hyperplasia of endocrine cells in general, as well as of enterocytes, in this material.

Further studies, on adult coeliacs as well as children, combined with studies on serum secretin levels, may establish whether the $\mathbf{S}$ cells are inactive and storing hormone, or hyperactive and storing excess. Further work should be undertaken on the pathology of $S$ cells in other digestive diseases. It would not be surprising if these cells, identified only recently, were found to be as fully involved in the pathology of the alimentary system as G cells, known and studied for so much longer.

This work was carried out with the help of grants from the Wellcome Trust, the British Diabetes Association (SRB), and the Heinz Foundation (MR).

\section{References}

Andersen, D. H. (1947). Celiac syndrome. VI. The relationship of celiac disease, starch intolerance and steatorrhea. J. Pediat., 30, 564-582.

Booth, C. C. (1970). Enterocyte in coeliac disease. I. Brit.med. J., 3, $725-731$.

Braganza, J., and Howat, H. T. (1972). Gallbladder inertia in coeliac disease. (Letter). Lancet, 1, 1133.

Capella, C., Solcia, E., and Vassallo, G. (1971). Ultrastructural and histochemical investigations on the endocrine cells of the intestinal mucosa. In Endocrinology, 1971: Proceedings of the Third International Symposium, pp. 283-290. Heinemann, London.

Coons, A. H., Leduc, E. H., and Connolly, J. M. (1955). Studies on antibody production. I. A method for the histochemical demonstration of specific antibody and its application to a study of the hyperimmune rabbit. J. exp. Med., 102, 49-59.

Di Magno, E. P., Go, V. L. W., and Summerskill, W. H. J. (1969). Pancreozymin secretion is impaired in sprue. Gastroenterology, $56,1149$.

Grant, D. B. (1973). Abnormal ins dlin secretion in children with coeliac disease. (Letter). Arch. Dis. Child., 48, 572.

Grimelius, L. (1968). A silver nitrate stain for $\alpha T$ cells in human pancreatic islets. Acta Soc. Med. upsalien., 73, 243-270.

Low-Beer, T. S., Heaton, K. W., Heaton, S. T., and Read, A. E. (1971). Gallbladder inertia and sluggish enterohepatic circulation of bile-salts in coeliac disease. Lancet, 1, 991-994.

Novis, B. H., Bank, S., and Marks, I. N. (1972). Exocrine pancreatic function in intestinal malabsorption and small bowel disease. Amer. J. dig. Dis., 17, 489-494.

Pearse, A. G. E. (1968). Common cytochemical and ultrastructural 
characteristics of cells producing polypeptide hormones (the APUD series) and their relevance to thyroid and ultimobranchial C cells and calcitonin. Proc. roy. Soc. B., 170, 71-80.

Pearse, A. G. E. (1969). The cytochemistry and ultrastructure of polypeptide hormone-producing cells of the APUD series and the embryologic, physiologic and pathologic implications of the concept. J. Histochem. Cytochem., 17, 303-313.

Polak, J. M., Bloom, S., Coulling, I., and Pearse, A. G. E. (1971a). Immunofluorescent localization of secretin in the canine duodenum. Gut, 12, 605-610.

Polak, J. M., Bussolati, G., and Pearse, A. G. E. (1971b). Cytochemical, immunofluorescence and ultrastructural investigation on the antral $G$ cells in hyperparathyroidism. Virchows Arch., Abt. B. Zellpath., 9, 187-197.

Polak, J. M., Coulling, I., Bloom, S., and Pearse, A. G. E. (1971c). Immunofluorescent localization of secretin and enteroglucagon in human intestinal mucosa. Scand. J. Gastroent., 6, 739-744.

Polak, J. M., Stagg, B., and Pearse, A. G. E. (1972). Two types of Zollinger-Ellison syndrome: immunofluorescent, cytochemical and ultrastructural studies of the antral and pancreatic gastrin cells in different clinical states. Gut, 13, 501-512.

Solcia, E., Capella, C., and Vassallo, G. (1969). Lead-haematoxylin as a stain for endocrine cells. Significance of staining and comparison with other selective methods. Histochemie, 20, 116-126.

Wormsley, K. G. (1970). Response to duodenal acidification in man. III. Comparison with the effects of secretin and pancreozymin. Scand. J. Gastroent., 5, 353-360.

Worning, H., Müllertz, S., Thaysen, E. H., and Bang, H. O. (1967). $\mathrm{pH}$ and concentration of pancreatic enzymes in aspirates from the human duodenum during digestion of a standard meal in patients with intestinal disorders. Scand. J. Gastroent., 2, 81-89. 